\title{
Efisiensi Usaha Peternakan Ayam Broiler dengan Sistem Manajemen Closed House dan Open House
}

\author{
Yanita Mutiaraning Viastika \\ Fakultas Peternakan, Universitas Wijayakusuma, Purwokerto \\ Correspondence email: yanitaveteriner@gmail.com
}

\begin{abstract}
Abstrak. Penelitian ini bertujuan mengidentifikasi rasio pendapatan usaha peternakan ayam broiler dengan sistem manajemen closed house dan open house. Metode penelitian yang digunakan adalah metode survei dengan menggunakan purposive sampling. Sebagai perlakuan adalah dua sistem manajemen kandang yaitu closed house dan open house. Metode penelitian mengunakan analisis keuntungan dan R/C rasio. Hasil penelitian menunjukkan bahwa 1) keuntungan yang diperoleh usaha peternak ayam broiler dengan sistem kandang open house lebih besar dari pada closed house. 2) usaha ternak ayam broiler yang menggunakan sistem kandang kandang open house dan closed house tergolong efisien. Temuan ini mengimplikasikan bahwa peternak ayam bisa memilih sistem kandang open house karena lebih menguntungkan.
\end{abstract}

Kata kunci: Peternakan Ayam, Efisiensi Usaha, Manajemen Peternakan

\begin{abstract}
This study aims to identify the ratio of broiler farm business income with closed house and open house management systems. The research method used was a survey method using purposive sampling. As treatment there are two cage management systems, namely closed house and open house. The research method uses profit analysis and $R / C$ ratio. The results showed that 1) the profit obtained by the broiler breeder business with the open house cage system was greater than that of the closed house. 2) the broiler chicken coop business that uses the open house and closed house systems is classified as efficient. This finding implies that chicken farmers can choose an open house cage system because it is more profitable.
\end{abstract}

Keywords: Chicken Farming, Business Efficiency, Animal Husbandry Management

\section{PENDAHULUAN}

Peternakan adalah suatu kegiatan dalam pemeliharaan hewan ternak untuk budidaya dan memperoleh keuntungan dari kegiatan tersebut (Rasyaf, 2002). Subsektor peternakan terbagi menjadi beberapa bagian diantaranya adalah ternak besar berupa sapi (perah/potong), kerbau, dan kuda, ternak kecil yang berupa kambing, domba, dan babi serta ternak unggas (ayam, itik, dan burung puyuh).

Produktivitas ternak terutama Peternakan ayam broiler adalah salah satu usaha ternak yang cukup potensial untuk dikembangkan, karena ayam broiler memiliki produktivitas yang lebih tinggi dibandingkan dengan ayam buras (Parmawati et al., 2018). Pertumbuhan berat badan pada ayam broiler sangat cepat, pemeliharaannya membutuhkan waktu yang relatif singkat, serta laju perputaran modalnya juga cepat, sehingga menjadi daya tarik bagi peternak untuk terjun dalam usaha peternakan ayam broiler. Menurut Raut et al., (2017) menunjukkan bahwa peternakan ayam broiler adalah bisnis yang menguntungkan dan keberhasilan bisnis unggas tergantung pada produksi tinggi dan kematian yang rendah.

Di Indonesia peluang untuk beternak ayam pada skala kecil maupun besar berpotensi baik. Hal tersebut ditunjukkan dengan rata-rata konsumsi daging ayam broiler per kapita per tahun yang mencapai $12,79 \mathrm{Kg}$ (Kementerian Pertanian, 2020). Pemerintah terus mendorong konsumsi per kapita untuk meningkatkan asupan gizi masyarakat dikarenakan nutrisi pada daging ayam broiler yang cukup baik, salah satu sumber protein yang mudah didapat dengan harga yang relatif murah dibandingkan dengan daging jenis lain. Berdasarkan jumlah konsumsi per kapita tersebut, setiap individu memperoleh nutrisi harian sebesar 19,73 kalori, 1,19 protein dan 1,63 lemak. Jumlah tersebut masih tergolong rendah dibandingkan dengan konsumsi perkapita negara lain (BPS, 2012).

Menurut Ratnasari et al., (2015) keunggulan ayam broiler adalah masa produksi yang relatif pendek \pm 32-35 hari, produktivitasnya tinggi, harga yang relatif murah, dan permintaan yang semakin meningkat. Ayam broiler merupakan jenis hewan ternak unggas yang tersedia sebagai sumber makanan, terutama sebagai penyedia protein hewani. Tahun 2019 populasi ayam broiler di Kabupaten Banyumas mencapai 11.741.324 ekor (BPS Banyumas, 2020). Jumlah tersebut tersebar di 27 Kecamatan di Banyumas dengan jumlah peternak ayam yang berskala besar mencapai 24 peternak. Di Kabupaten Banyumas dalam proses ternak menggunakan system manajemen kandang closed house dan open house. Berdasarkan hasil survey prapenelitian para peternak ayam memiliki alasan tersendiri dalam memilih system kandang yang digunakan, salah satu alasanya dalam menekan biaya produksi yang dikeluarkan dalam perawatan kandang.

Dalam menunjang keberhasilan bertenak ayam broiler hal yang tidak kalah penting yaitu kualitas kandang ayam. Dengan kualitas kandang ayam yang memiliki standart yang baik akan memberikan kenyamanan dan melindungi ternak dari panas matahari, hujan, angin, udara dingin dan mencegah gangguan 
seperti predator (Susanti et al., 2016). Selain itu, kandang yang baik juga memudahkan para peternak dalam tatalaksana yang meliputi pemeliharaan dalam pemberian pakan dan minum.

Usaha peternakan ayam broiler menggunakan sistem manajemen kandang closed house dan open house yang seluruhnya berorientasi pada pencapaian keuntungan yang maksimal. Kedua sistem kandang tersebut memiliki kekurangan dan kelebihan seperti besarnya modal dan biaya perawatan kandang serta mortalitas ayam broiler. Kedua system manajemen kandang tersebut akan berpengaruh besar terhadap penerimaan yang diperoleh peternak. Penggunaan sistem manajemen closed house dan open house berhubungan dengan alokasi biaya yang akan mempengaruhi pendapatan peternak ayam broiler.

Hoddi et al., (2011) menyatakan bahwa keuntungan yang diperoleh peternak ayam broiler merupakan hasil dari penjualan ternak dikurangi dengan biaya-biaya yang dikeluarkan selama masa produksi. Namun demikian, usaha peternakan ayam dapat dikatakan berhasil apabila telah mencapai standar dan tujuan yang telah ditetapkan. Dengan demikian, perlunya perhitungan yang dapat menunjukkan keuntungan yang didapatkan oleh para pelaku peternak ayam. Revenue Cost Ratio (R/C Ratio) merupakan metode matematis yang membandingkan antara penerimaan dengan biaya. Suatu usaha atau proyek dikatakan menguntungkan jika perbandingan antara penerimaan dan biaya bernilai lebih besar dari angka satu.

Perbedaan dalam sistem manajemen kandang yang digunakan oleh peternak ayam broiler dalam hal ini closed house dan open house tentu mempengaruhi usaha ternaknya. Kedua system manajemen kandang tersebut tentu memengaruhi biaya yang dikeluarkan oleh peternak dalam proses pembesaran ayam, sehingga akan memengaruhi profit yang diperoleh. Oleh karena itu, perlunya penelitian lebih lanjut mengenai pendapatan dan efisiensi usaha pada peternakan ayam broiler yang menggunakan sistem manajemen kandang closed house dan open house. Selain itu, diharapkan hasil dari studi empiris ini dapat digunakan sebagai pijakan dalam merumuskan kebijakan yang tepat untuk pengguna system manajemen kandang, sehingga dapat meningkatkan pendapatan peternak ayam broiler pada umumnya.

\section{METODE}

Sampel yang digunakan dalam penelitian ini adalah semua peternak ayam yang mengunakan system manajemen kandang closed house dan open house di Kabupaten Banyumas yaitu sebanyak 24 peternak ayam. Data yang diambil pada penelitian ini adalah data primer yang diperoleh dari peternak ayam broiler dan data sekunder diperoleh dari instansi terkait. Penelitian ini dilaksanakan pada bulan Maret sampai dengan Mei 2020 per satu kali produksi pembesaran ayam broiler.

Metode analisis yang digunakan dalam penelitian ini adalah sebagai berikut:

1. Perhitungan Profit/Laba

Analisis ini digunakan untuk mengetahui jumlah keuntungan yang diperoleh pelaku usaha dalam hal ini peternak ayam broiler. Analisis ini dilakukan dengan cara menghitung selisih antara total penerimaan dengan total biaya (Sukirno, 2002). Profit atau laba dapat dihitung dengan rumus sebagai berikut:

$\Pi=\mathrm{TR}-\mathrm{TC}$

Keterangan:

$\Pi$ : Profit/Laba

TR : Total Revenue (Total Penerimaan)

TC : Total Cost (Total Biaya)

2. R/C Rasio

Untuk mengetahui efisiensi usaha peternak ayam broiler dihitung menggunakan $\mathrm{R} / \mathrm{C}$ ratio yaitu perbandingan antara jumlah penerimaan dan total biaya (Soekartawi, 2003). Berikut ini rumus R/C rasio yang digunakan dalam penelitian ini:

$\mathrm{R} / \mathrm{C}$ Rasio $=\mathrm{TR} / \mathrm{TC}$

Keterangan :

TR : Total Revenue (Total Penerimaan)

TC : Total Cost (Total Biaya)

Dalam perhitungan $\mathrm{R} / \mathrm{C}$ rasio memiliki kriteria pengujian sebagai berikut:

a. $\mathrm{R} / \mathrm{C}>1$ artinya usaha ternak broiler yang dilakukan adalah efisien.

b. $\mathrm{R} / \mathrm{C}<1$ artinya usaha ternak broiler yang dilakukan adalah tidak efisien.

c. $\mathrm{R} / \mathrm{C}=1$ artinya usaha ternak broiler yang dilakukan adalah mencapai titik impas.

Total penerimaan dalam penelitian ini adalah penjualan ayam, tempat pakan, dan kotoran ayam. Menurut Azizah et. al., (2013) menyatakan bahwa penerimaan yang diterima peternak berasal dari beberapa aktivitas antara lain penjualan hasil, bonus dari pihak inti dan penjualan kotoran ayam.

Selain itu, biaya total dalam penelitian ini terdiri dari biaya tetap dan biaya variabel. Biaya tetap yang dikeluarkan oleh peternak meliputi penyusutan kandang, penyusutan peralatan, sewa kandang dan pajak bumi dan bangunan. Biaya variabel yang dikeluarkan peternak plasma meliputi biaya bibit ayam.

\section{HASIL DAN PEMBAHASAN}

Kebutuhan protein hewani semakin meningkat seiring bertambahnya jumlah penduduk dan pendapatan masyarakat. Salah satu komoditi peternakan yang dapat menjadi sumber pemenuhan kebutuhan protein adalah ayam pedaging (broiler). Kebutuhan daging ayam mengalami peningkatan setiap tahunnya karena 
harganya yang terjangkau oleh semua kalangan masyarakat.

Ayam broiler adalah jenis ternak unggas yang memiliki laju pertumbuhan sangat cepat dengan usia panen 35 hari. Keunggulan broiler didukung oleh sifat genetik dan keadaan lingkungan yang meliputi makanan, temperatur lingkungan, dan pemeliharaan (Umam dkk, 2015).

Peningkatan jumlah penduduk dan kebutuhan konsumsi daging ayam broiler menurut Direktorat Jenderal Peternakan dan Kesehatan Hewan, berdasarkan hasil Survei Konsumsi Bahan Pokok (VKBP) tahun 2017 dan Survei Sosial Ekonomi Nasional (Susenas) tahun 2019 yang dilaksanakan BPS, bahwa konsumsi daging ayam ras adalah sebesar $12,79 \mathrm{~kg} / \mathrm{kapita} / \mathrm{tahun}$. Sedangkan kisaran harga daging ayam broiler per kilogramnya sebesar Rp 32.000 sampai dengan Rp 44.350 (PIHPS, 2021).

Hasil produksi ayam broiler yang baik dapat dicapai dengan menerapkan manajemen peternakan yaitu penggunaan bibit yang unggul, pemberian pakan yang berkualitas, serta sistem perkandangan harus memperhatikan aspek kenyamanan dan kesehatan ternak (Nuriyasa, 2003).
Salah satu faktor penting yang berpengaruh dalam keberhasilan pemeliharaan ayam broiler adalah kandang. Kandang merupakan tempat ayam tinggal dan beraktivitas sehingga kandang yang nyaman sangat berpengaruh terhadap pencapaian produktivitas yang baik. Kandang merupakan sarana tempat tinggal ternak mulai awal kehidupan sampai dengan panen, sehingga sistem perkandangan perlu diperhatikan seperti faktor suhu, kelembaban, tingkat kepadatan ternak dan jenis lantai kandang yang dipergunakan agar menunjang produksinya secara optimal (Insani, 2010).

Sistem kandang yang perlu diperhatikan dalam menunjang tercapainya produktivitas ayam broiler diantaranya adalah desain dan peralatan yang sesuai, faktor biaya, diikuti dengan kemudahan dalam mendapatkan bahan dan peralatan serta ketahanan bahan dan peralatan. Dengan demikian, kandang dapat bertahan lama dengan menyediakan lingkungan yang nyaman bagi ayam broiler, serta mudah dalam pengontrolan (Ulfah dan Joko, 2011).

Penelitian dilakukan di Kabupaten Banyumas terkait efisiensi usaha peternakan ayam broiler dengan sistem manajemen Closed house dan Open house. Tabel 1 menunjukkan komponen biaya produksi ayam broiler dengan sistem closed house dan open house.

Tabel 1. Biaya Produksi Ayam Broiler dengan Sistem Closed House dan Open House (Rupiah)

\begin{tabular}{ccccc}
\hline No & Sistem Kandang & Total Biaya Tetap (1) & Total Biaya Variabel $(2)$ & Total Biaya $(1+2)$ \\
\hline 1. & Closed House & 26.800 .000 & 5.521 .176 .000 & 5.547 .976 .000 \\
2. & Open House & 66.010 .000 & 4.214 .627 .000 & 4.280 .637 .000 \\
\hline
\end{tabular}

Sumber: data primer diolah.

Biaya produksi merupakan biaya yang dikeluarkan oleh peternak yang terdiri dari biaya tetap dan biaya variabel. Biaya tetap pada pemeliharaan ayam meliputi biaya penyusutan kandang dan biaya tenaga kerja. Sementara itu, biaya tidak tetap pada pemeliharaan ayam broiler meliputi: bibit, pakan, obatobatan, listrik, sekam, kapur, gas LPG.

Tabel 1 menunjukkan bahwa total biaya produksi ayam broiler yang mengunakan manajemen kandang closed house lebih besar jika dibandingkan dengan open house. Hal tersebut tentu akan memengaruhi keuntungan yang didapatkan oleh pengusaha ayam broiler. Hal ini dikarenakan kandang dengan sistem open house memerlukan biaya operasional yang cukup murah dengan pembangunan kandang terbuka dapat memaksimalkan fungsi ventilasi karena intensitas angin relatif tinggi, memaksimalkan cahaya matahari serta memaksimalkan intensitas yang tinggi, sehingga total biaya produksi dapat ditekan.

Berikut Tabel 2 yang menunjukkan pendapatan yang diterima oleh peternak ayam broiler di Kabupaten Banyumas yang mengunakan sistem kandang closed house dan open house.

Tabel 2. Pendapatan Peternak dengan Sistem Kandang Closed House dan Open House (Rupiah).

\begin{tabular}{ccccc}
\hline \multirow{2}{*}{ No } & \multirow{2}{*}{ Sistem Kandang } & \multicolumn{2}{c}{ Penjualan } & Pendapatan \\
\cline { 3 - 4 } & & Ayam (1) & Karung (2) & 5.919 .382 .500 \\
\hline 1. & Closed House & 5.902 .350 .000 & 17.032 .500 & 4.710 .830 .000 \\
2. & Open House & 4.697 .450 .000 & 13.380 .000 & \\
\hline
\end{tabular}

Sumber: Data primer diolah

Tabel 2 menunjukkan bahwa pendapatan peternak ayam broiler di Kabupaten Banyumas. Penerimaan yang diperoleh oleh pengusaha ayam meliputi penjualan dari ayam dan karung. Penerimaan dalam peternakan ayam broiler dapat bersumber dari penjualan ayam, penjualan karung bekas pakan dan penjualan kotoran ayam. Pada tabel 2 menunjukkan bahwa sumber penerimaan terbesar adalah dari penjualan ayam yaitu sebesar 99\%. Penjualan karung bekas pakan dan kotoran ayam juga merupakan sumber penerimaan 
lainnya dalam usaha peternakan ayam broiler. Data BPS menunjukkan bahwa penjualan ayam merupakan sumber terbesar penerimaan peternakan ayam broiler yaitu sebesar $98,5 \%$, penerimaan lainnya bersumber dari penjualan karung bekas pakan sebesar $0,8 \%$, dan $0,7 \%$ dari penjualan kotoran ayam. Penerimaan terbanyak diterima oleh pengusaha ayam broiler yang menggunakan sistem kandang closed house. Namun demikian perlu diketahui bersama jika pendapatan dari pengusaha ayam broiler sangat dipengaruhi oleh biaya produksi mulai dari harga benih ayam, harga pakan, dan biaya perawatan kandang dan lain sebagainya (Setiawan et al., 2018). Berikut Tabel 3 yang menunjukkan perbedaan keuntungan yang diterima oleh pengusaha ayam broiler.

Tabel 3. Keuntungan Peternak Ayam Broiler dengan Sistem Kandang Closed House dan Open House (Rupiah).

\begin{tabular}{ccccc}
\hline No & Sistem Kandang & Penerimaan $(1)$ & Biaya Produksi (2) & Keuntungan $(1+2)$ \\
\hline 1. & Closed House & 5.919 .382 .500 & 5.547 .976 .000 & 371.406 .500 \\
2. & Open House & 4.710 .830 .000 & 4.280 .637 .000 & 430.193 .000 \\
\hline
\end{tabular}

Sumber: data primer diolah

Pendapatan adalah laba usaha tani dalam usaha satu tahun untuk pemilik, upah, manajemen dan kapital milik sendiri yang dipakai untuk usaha. Hoddi et al. (2011) menyatakan bahwa keuntungan yang diperoleh peternak ayam broiler merupakan hasil dari penjualan ternak dikurangi dengan biaya-biaya yang dikeluarkan selama masa produksi.

Tabel 3 menunjukkan bahwa keuntungan yang diterima oleh peternak ayam yang mengunakan sistem kandang open house jauh lebih besar. Pemeliharaan ayam broiler pada umumnya menggunakan kandang alas litter. Kandang dengan sistem open house dikatakan menguntungkan dan efisien dikarenakan biaya operasional yang digunakan cukup murah dalam pembangunan. Selain itu, kelebihan kandang open house lainnya adalah dengan dapat memaksimalkan fungsi ventilasi karena intensitas angin relatif tinggi serta memaksimalkan cahaya matahari, sehingga total biaya produksi dapat ditekan.

Sementara itu, sistem kandang closed house membutuhkan investasi dan beban operasional yang cukup tinggi dalam pembangunannya. Selain itu, kandang closed house harus disertai dengan infrastruktur dan penguasaan teknologi yang baik. Temuan ini sejalan dengan penelitian Putra et al, (2020) yang menganalisis keuntungan usaha tani kopi dengan mengunkan pendekatan metode hayami yang menunjukkan bahwa usaha tani kopi terbilang menguntungkan.

Untuk mengetahui efisiensi usaha peternak ayam broiler dihitung menggunakan $\mathrm{R} / \mathrm{C}$ ratio yaitu perbandingan antara jumlah penerimaan dan total biaya (Soekartawi, 2010). Berikut ini tabel 4 yang menunjukkan $\mathrm{R} / \mathrm{C}$ rasio yang digunakan dalam penelitian ini:

Tabel 4. R/C Ratio dari Sistem Kandang Closed House dan Open House

\begin{tabular}{cccccc}
\hline No & Sistem Kandang & Biaya Produksi (1) & Penerimaan (2) & R/C Rasio (1/2) & Keterangan \\
\hline 1. & Closed House & 5.547 .976 .000 & 5.919 .382 .500 & 1,066 & Efisien \\
2. & Open House & 4.280 .637 .000 & 4.710 .830 .000 & 1,100 & Efisien \\
\hline
\end{tabular}

Sumber: Data primer diolah

Suatu perusahaan dapat dikatakan berhasil apabila telah mencapai standar dan tujuan yang telah ditetapkan. R/C Ratio yaitu perbandingan antara penerimaan dengan biaya. Suatu usaha atau proyek dikatakan menguntungkan jika perbandingan antara revenue dan cost bernilai lebih besar dari angka satu. Hasil perhitungan menunjukkan bahwa efisiensi usaha ayam broiler di Kabupaten Banyumas sudah tergolong efisien. Hal tersebut dapat dilihat pada $\mathrm{R} / \mathrm{C}$ rasio pada Tabel 4. Jika dilihat dari nilai $\mathrm{R} / \mathrm{C}$ rasio menunjukkan usaha ayam broiler yang menggunakan sistem kandang open lebih efisien karena memiliki nilai yang lebih besar.

Namun demikian sistem kandang open house juga memiliki kekurangan yaitu kandang yang sangat dipengaruhi oleh kondisi lingkungan dari luar seperti panas, kelembapan udara dan angin, terutama di
Indonesia dengan iklim tropis dan perubahan cuacanya sangat ekstrim. Di daerah dataran rendah suhu bisa menjadi sangat tinggi dan angin cukup kencang. Sementara itu di dataran tinggi suhu sangat dingin disertai dengan kelembapan tinggi (Tamalludin, 2012). Di samping itu kandang closed house meskipun membutuhkan biaya produksi yang cukup tinggi, akan tetapi memiliki kelebihan kapasitas atau populasi yang jauh lebih banyak, ayam lebih terjaga dari gangguan luar baik fisik, cuaca, maupun serangan penyakit, terhindar dari polusi, keseragaman ayam lebih bagus, dan pakan lebih efisien. Kandang ini juga memberikan kemudahan karena kondisi angin akan lebih terkontrol dibandingkan dengan kandang tipe terbuka.

Menurut Ulfah dan Joko (2011) menyatakan bahwa untuk menunjang produktivitas ayam broiler secara optimal maka perlu diperhatikan dalam memilih 
sistem kandang ayam broiler diantaranya desain dan peralatan yang sesuai. Namun, pertimbangan utamanya dilihat dari faktor biaya. Selanjutnya diikuti dengan kemudahan dalam mendapatkan bahan dan peralatan serta ketahanan bahan dan peralatan. Hal tersebut dikarenakan kandang harus tahan lama dengan menyediakan lingkungan yang nyaman bagi ayam broiler, serta mudah dikontrol.

\section{SIMPULAN}

Sistem kandang yang digunakan oleh peternak ayam broiler dalam hal ini closed house dan open house tentu mempengaruhi usaha ternaknya. Kedua system manajemen kandang tersebut tentu memengaruhi biaya yang dikeluarkan oleh peternak dalam proses pembesaran ayam, sehingga akan memengaruhi profit yang diperoleh. Hasil penelitain menunjukkan bahwa keuntungan yang diperoleh dari sistem kandang open house lebih besar daripada closed house. Namun demikian jika ditinjau dari efisinesi usaha open house dan closed house memiliki nilai $\mathrm{R} / \mathrm{C}$ rasio lebih dari 1, yang menunjukkan usaha ternak ayam broiler samasama efisien. Namun dapat dikatakan jika usaha ayam yang mengunakan sistem kandang open house lebih efisien karena nilai $\mathrm{R} / \mathrm{C}$ rasionya lebih tinggri dari pada closed house. Implikasi kebijakan dalam penelitian ini adalah bagi pengusaha pembesaran ayam broiler lebih efisien jika menerapkan sistem kandang yang open house karena lebih efisien dan menguntungkan.

\section{DAFTAR PUSTAKA}

Azizah, N., Utami, H. D., \& Nugroho, B. A. (2013). Analisis pola kemitraan usaha peternakan ayam pedaging sistem closed house di Plandaan Kabupaten Jombang. Jurnal Ilmu-ilmu peternakan, 23(2), 1-5.

BPS. (2012). Profil Pangan dan Pertanian. Diakses 9 Maret 2021.

BPS. (2018). Populasi Unggas Menurut Kabupaten/kota dan Jenis Unggas di Provinsi Jawa Tenga (KG), 2018-2020.

https://jateng.bps.go.id/indicator/24/490/1/popula si-unggas-menurut-kabupaten-kota-dan-jenisunggas-di-provinsi-jawa-tenga.html. Diakses tanggal 9 Maret 2021.

BPS. 2018. Populasi Ayam Ras Pedaging Menurut Provinsi.

https://www.bps.go.id/linkTableDinamis/view/i d/1034. Diakses tanggal 9 Maret 2021.

BPS Banyumas. 2020. https://banyumaskab.bps.go.id/. Diakses tanggal 9 Maret 2021.

Ditjen $\mathrm{PKH}$. 2016. http://data.jatengprov.go.id/organization/dinaspeternakan-dan-kesehatan-hewan-provinsi-jawatengah. Diakses tanggal 10 Maret 2021.
Hoddi, A. H, M. B. Rombe, dan Fahrul. 2011. Analisis pendapatan peternakan sapi potong di Kecamatan Tanete Rilau, Kabupaten Barru (revenue analysis cattle ranch in sub tanete Rilau Barru). Jurnal Agribisnis, 10(3): 25-32.

Kementerian Pertanian. 2020. Kementan: Stok Pangan Asal Hewan Jelang HBKN Aman. https://ditjenpkh.pertanian.go.id/kementan-stokpangan-asal-hewan-jelang-hbkn-aman. Diakses tanggal 10 Maret 2021.

Insani, G.A. (2010). Optimalkan Produksi Saat Heat Sterss. Feed Journal Basic. http://www.feedjournal.com/basicp apers/WEBlab.UnggasUGM.pdf.

Nuriyasa, I. M. (2003). Pengaruh Tingkat Kepadatan dan Kecepatan Angin dalam Kandang Terhadap Indeks Ketidaknyamanan dan Penampilan Ayam Pedaging. Majalah Ilmiah Peternakan, Fakultas Peternakan, Unud. Hal 99-103.

PIHPS. 2021. Pusat Informasi Harga Pangan Strategis Nasional. https://hargapangan.id/tabelharga/pasar-modern/komoditas. Diakses tanggal 8 Maret 2021.

Parmawati, R., Mashudi, M., Budiarto, A., Suyadi, S., \& Kurnianto, A. S. (2018). Developing sustainable livestock production by feed adequacy map: A case study in Pasuruan, Indonesia. Tropical Animal Science Journal, 41(1), 67-76.

Putra, S., Istiqomah, I., Gunawan, D., \& Purnomo, S. (2020). Analisis Pendapatan dan Nilai Tambah Industri Pengolahan Kopi : Pendekatan Metode Hayami. Efficient: Indonesian Journal of Development Economics, 3(3), 994-1005. https://doi.org/10.15294/efficient.v3i3.43518

Raut, S. D., Malave, D. B. \& Gore, S. T. 2017. Financial feasibility of investment in Broiler poultry units in Raigad district of Maharashtra. International Research Journal of Agricultural Economics and Statistics. 8(1):170-175.

Ratnasari, R., Sarengat, W., \& Setiadi, A. (2015). Analisis pendapatan peternak ayam broiler pada sistem kemitraan di Kecamatan Gunung Pati Kota Semarang. Animal Agriculture Journal, 4(1), 4753.

Rasyaf. (2002). Beternak Ayam Pedaging. Penerbit Kanisius. Yogyakarta.

Sukirno, S. (2002). Teori Mikro Ekonomi. Cetakan Keempat Belas. Rajawali Press: Jakarta

Soekartawi. (2010). Agribisnis: Teori dan Aplikasinya. Jakarta : PT Raja Grafindo Persada..

Tamalludin, F. (2014). Panduan Lengkap Ayam Broiler. Penebar Swadaya. Jakarta.

Ulfah, M \& Joko D. S. (2011). 7 Jurus Menjadi Peternak Ayam Ras Pedaging. Penerbit Swadaya. Jakarta. 
Yanita Mutiaraning Viastika, Efisiensi Usaha Peternakan Ayam Broiler dengan Sistem Manajemen Closed House dan Open House

Umam, M.K., H.S. Prayogi, \& V.M.A Nurgiatiningsih. (2015). Penampilan Produksi Ayam Pedaging Yang Dipelihara Pada Sistem Lantai Kandang Panggung dan Kandang Bertingkat. Jurnal-Jurnal Ilmu Peternakan. 24 (3) : 79-87. 